\title{
Innovators and early adopters in the diffusion of innovations: A literature review
}

\section{Ozgur Dedehayir*}

Queensland University of Technology, 2 George Street, 4000 Brisbane, Australia.

E-mail: ozgur.dedehayir@qut.edu.au

\section{Roland Ortt}

TU Delft, Mekelweg 2, 2628 CD Delft, The Netherlands.

E-mail: j.r.ortt@tudelft.nl

\section{Carla Riverola}

La Salle - Universitat Ramon Llull, Sant Joan la Salle 42, Barcelona 08022, Spain.

E-mail: criverola@salleurl.edu

\section{Francesc Miralles}

La Salle - Universitat Ramon Llull, Sant Joan la Salle 42, Barcelona 08022, Spain.

E-mail: fmiralles@salleurl.edu

\section{* Corresponding author}

\begin{abstract}
Despite accounting for a very small percentage of the population that adopts an innovation, the 'innovators' and 'early adopters' - representing the two earliest groups of individuals to acquire the new product or service - play a crucial role in the dissemination of the innovation to larger market segments. The objective of this paper is to understand the characteristics of these individuals that positively influence their decisions to adopt innovations. We argue that awareness of these traits will enable firms to attain speedier uptake of their offerings while aiding policymakers achieve quicker and wider proliferation of new technologies intended for societal benefit. We undertake a review of the literature studying the diffusion of innovations, and show future directions that this framework should take to analyse the adoption lifecycle.
\end{abstract}

Keywords: Innovation; diffusion; new product development; product life cycle; segmentation. 


\section{Introduction}

Rogers (2003, p.12) defines an innovation as "an idea, practice, or object that is perceived as new by an individual or other unit of adoption". The earliest members of the population to acquire the innovation are referred to as innovators and early adopters. Individuals belonging to these groups carry commonalities, such as novelty seeking behaviour and price insensitivity, which motivate them to adopt a new product or service earlier than others. More significant, however, is their role in communicating or convincing the benefits of the innovation and its uses to the remainder of the population. The early identification of innovators and early adopters is therefore important for businesses developing new products, "since it assists in the process of tailoring each element of the marketing mix to the requirements and behaviors of those buyers who initiate markets and without whom the social comparison that leads to diffusion would often not occur.” (Foxall and Goldsmith, 1994, p. 35-36).

These viewpoints are central to the adoption and diffusion of innovations theory advanced by Everett Rogers. Since Rogers's seminal work - "Diffusion of Innovations" (1962) - which builds on the prior contribution of Griliches (1957) exploring the diffusion of hybrid corn, a plethora of studies have analysed the diffusion of innovations in a variety of contexts ranging from agriculture (e.g. Berger, 2001), to health care (e.g. Berwick, 2003) and information technology (e.g. Jeyaraj et al., 2006). Our objective is to provide a synthesis of this literature that spans over 50 years. In this endeavour we begin by providing an overview of the large body of empirical work on innovators' and early adopters' characteristics completed and published between the 1960s and 1995. Given that many of these sources are not widely available electronically, our review relies on the conclusions and methodological issues raised in important review papers published in the mid-1990s. We then proceed with a systematic search and analysis of empirical studies conducted after 1995 using the ISI Web of Science database, which allowed us to peruse 470 relevant scientific publications, of which 70 were selected to form the core of our analysis.

We focus on the following research questions:

- What are the characteristics of innovators and early adopters?

- How do post 1995 empirical studies relate to the work done before 1995?

Our paper begins with a brief overview of the theoretical foundation and results of empirical research prior to 1995 exploring the innovators' and early adopters' characteristics (section 2). We then discuss our methods (section 3) and present the results of our literature review (section 4). In this section we will propose a conceptual model that relates a number of independent variables, which explain innovation adoption. In the conclusion (section 5) we discuss whether methodological weaknesses underscored in earlier contributions have been taken into account in later works, and subsequently explore future research avenues (section 6). 


\section{The diffusion of innovations}

The diffusion of innovation theory operates at both individual and aggregate levels of analysis. At the individual level, it focuses on the process of adoption, which essentially involves: (i) the innovation; (ii) an individual that has already adopted the innovation; (iii) another individual that is yet to adopt the innovation; and (iv) some kind of communication channel that allows these two individuals to exchange information (Rogers, 1995; Eerkens and Lipo, 2014). Firstly, the theory explains the sequence of stages through which the individual, who is yet to adopt the innovation, will progress in making a final decision to adopt or not to adopt (Rogers, 1995; Blackburn, 2011). Secondly, the theory explains how communication can influence this individual process in multiple ways. Communication between individuals, for example in word-of-mouth processes, or observation of individuals that adopt and use the innovation and thereby stimulate other individuals to imitate that behaviour, and the communication transferring information about the innovation through mass media, all have their own distinct roles in the individual process of adoption.

At the aggregate level of analysis, the diffusion of innovation theory suggests the manifestation of an S-curved cumulative adoption pattern, as the population of individuals acquire the innovation over time. This temporal pattern further proposes that some members of the population adopt earlier than others, reflecting their level of innovativeness, in other words, "the degree to which an individual is relatively earlier in adopting an innovation than other members of his social system" (Rogers and Shoemaker, 1971, p. 27). Based on the timeliness of their adopting behaviour, Rogers distinguishes groups of individuals that form the population according to their socioeconomic, personality, and communication behaviour characteristics (Faiers and Neame, 2006)

\section{Overview of the findings regarding innovator characteristics prior to 1995}

An overview of empirical studies exploring the characteristics of innovators and early adopters conducted since the 1960s appear in several publications (Engel, Blackwell and Miniard, 1990; Foxall and Goldsmith, 1994; Robertson, 1971; Rogers and Shoemaker, 1971), although here we focus only on two - Engel et al. (1990) and Foxall and Goldsmith (1994) - since they have greater coverage of the pre-1995 period. These papers firstly provide broad categories of characteristics, distinguished on the basis of a large number of studies. Engel et al. (1990) suggest these categories to include: (1) socioeconomic characteristics (e.g. age, education); (2) personality variables (e.g. empathy, dogmatism); and (3) characteristics related to the communication behaviour (e.g. social participation, interconnectedness with the social system). Meanwhile, Foxal and Goldsmith (1994) add two further categories to this list: (4) perceptions of new products, and (5) purchase and consumption patterns. It is interesting to note that the first three categories of characteristics are generic i.e., not directly related to a particular innovation, whereas the last two categories are specific i.e., related to the product category to which the innovation belongs.

The papers secondly show that some of the widely held notions about innovators and early adopters of innovations are not confirmed, or are only weakly confirmed. The most salient observation is that innovator characteristics vary per product category. For 
example, innovators in fashion do not have the same characteristics as innovators in IT. At the same time, some of the pre-1995 studies indicate that across different innovations the earliest adopters are not younger than later adopters, and they are also not less dogmatic than later adopters, as we might theoretically anticipate. These findings would plea for a distinction between generic innovator characteristics (such as the first three broad categories mentioned above) and specific innovator characteristics (such as the last two categories mentioned above). If this distinction is important then we would expect the specific characteristics (with a direct relationship to the product category to which the innovation belongs) to have a stronger relationship with early adoption than the generic characteristics.

Engel et al. (1990, p. 696-697) thirdly indicate that (the speed of) diffusion depends on other variables, in addition to early adopter characteristics. These include the competitive intensity of the innovation's main supplier, supplier reputation, supplier's resource commitments, availability of standards for the innovation, coordination of and cooperation between complementary actors required to supply the innovation, and all of the innovation's complementary products and services. It is interesting to see that fast diffusion requires conditions to be optimal in the entire market system: on the supply side, the demand side, and the guiding institutions in which the supply- and demand side actors operate.

Fourthly, the papers propose that early adopters have similar characteristics to 'early rejecters', in other words, those who decide not to adopt the innovation. Labay and Kinnear (1981) demonstrate the remarkable similarity between early rejecters and early adopters of solar panels, in stark contrast to the diffusion of innovation theory that sees rejecters as falling outside the groups of adopters.

And finally, while early adopters are deemed to be opinion leaders, the papers underline that innovativeness and opinion leadership are distinctly different. This difference is reflected in the sometimes deviant behaviour of innovators. An example is provided by Rogers (2003) himself, who describes the first users of a water well installed by development aid workers as likely to be a person that is an outcast of the village. In this instance, the early adopter is not an opinion leader, and in fact may discourage others from making the same adoption decision.

\section{Method}

Following the summary of the empirical work undertaken prior to 1995, we now proceed to the systematic literature review of contributions after 1995. To this end, we followed a step-wise procedure (Hart, 1998). We commenced by consulting the ISI Web of Science database in February 2016, and using the keyword innovator* in conjunction with the keyword diffusion in the title, abstract, and keywords of publications, identified a set of scientific papers appearing in journals, books, and conference proceedings $(\mathrm{N}=259)$. We repeated this exercise by using the keyword early adopter* in conjunction with the keyword diffusion to identify a second set of scientific papers $(\mathrm{N}=211)$. In the following step we implemented two inclusion criteria to omit publications that would not contribute to our study. Firstly, we focused on papers in which the decision to adopt was investigated for individuals. In practice individual adopters can belong to consumer households (and hence belong to the business-to-consumer (B2C) market) or to organisations (and hence belong to the business-to-business (B2B) market). As a result, 
papers studying organisational adoption involving multiple individuals, sometimes in different departments, were left out. Secondly, we precluded publications that did not employ the diffusion of innovations theory with a sufficient level of depth (e.g. in cases where the keywords appeared in the reference list of the papers, or were merely mentioned without any subsequent analysis). After careful examination of the abstracts of all publications with respect to these criteria, we selected 59 papers that were deemed to be most relevant to the purpose of our survey and warranting a thorough analysis.

The collection of papers were then read through independently by the authors and analysed to extract two groups of data: (i) contextual; and (ii) categorical. Contextual data included the empirical setting (e.g. medical), the diffusing innovation (e.g. internet-based patient education programme) and the authors of a given publication (e.g. Anttila et al., 2011). In addition we included whether the innovation diffused in a business-to-business or business-to-consumer setting. Finally, the type of innovation was characterised as a product, service or process. The categorical data, in turn, related directly to the question driving our research, and included dependent variables (e.g. adoption) and independent variables (e.g. characteristics of individuals that may explain adoption) used in the empirical investigations, as well as the main outcomes of these investigations such as the verification of hypotheses or the discovery of additional variables that explain the dependent variable. The data recorded from this analysis was then synthesized to provide a comprehensive set of characteristics that define individuals belonging to the innovators and early adopter categories.

\section{Results}

Our review of the literature revealed the examination of a wide spectrum of innovations, and the employment of a diverse set of variables in these studies. We commenced our meta-analysis of this large dataset by implementing two grouping strategies. First, we designated the studied innovations into one of several generic categories, which essentially define the broad empirical contexts studied by scholars (see Table 1).

As the table shows, a majority of scholarly works over the past twenty years explore the diffusion of 'electronics, IT, internet, and social media' as well as the 'medical, health, and pharmaceutical' innovations. There is also a notable number of empirical studies of the 'agriculture and farming' context, following the footsteps of seminal scholars such as Rogers (1962) and Grilliches (1957). The heterogeneity of the 59 studies included in our analysis is also reflected in the market context (i.e. B2B or B2C) and the type of innovation (i.e. product, service or process) examined. The majority of the studies (38 out of 59) were set in a B2C context, with the remainder in a B2B context. Meanwhile a majority of the studies (33 out of 59) focused on product rather than service (12) or process innovations (14). We also note that the B2B context and process innovations are overrepresented in the empirical setting of the medical, health and pharmaceutical sector as well as the agriculture and farming sector. 
Table 1 Empirical settings and innovations studied by scholars

\begin{tabular}{|c|c|c|c|c|}
\hline Empirical setting & Innovation & Study & Context & Type \\
\hline electronics, IT, internet, and & internet services & Atkin et al., 1998 & $\mathrm{~B} 2 \mathrm{C}$ & service \\
\hline \multirow{19}{*}{ social media } & e-book readers & Bergstrom and Hoglund, 2014 & $\mathrm{~B} 2 \mathrm{C}$ & product \\
\hline & consumer electronics & Boyd and Mason, 1999 & $\mathrm{~B} 2 \mathrm{C}$ & product \\
\hline & Multimedia Message Service & Chiyangwa and Alexander, 2015 & $\mathrm{~B} 2 \mathrm{C}$ & service \\
\hline & LCD TV & Cho and Koo, 2012 & $\mathrm{~B} 2 \mathrm{C}$ & product \\
\hline & personal shopping assistant & Evanschitzky et al., 2015 & $\mathrm{~B} 2 \mathrm{C}$ & product \\
\hline & internet content filtering software & Jin, 2013 & $\mathrm{~B} 2 \mathrm{C}$ & product \\
\hline & online travel booking services & Kah et al., 2016 & $\mathrm{~B} 2 \mathrm{C}$ & service \\
\hline & wireless phones & Kauffman and Techatassanasoontorn, 2009 & $\mathrm{~B} 2 \mathrm{C}$ & product \\
\hline & online banking services & Kavak and Demirsoy, 2009 & $\mathrm{~B} 2 \mathrm{C}$ & service \\
\hline & smart phones & Lee, 2014 & $\mathrm{~B} 2 \mathrm{C}$ & product \\
\hline & broadband internet & Lin and $\mathrm{Wu}, 2013$ & $\mathrm{~B} 2 \mathrm{C}$ & service \\
\hline & e-learning & Loogma et al., 2012 & B2B & process \\
\hline & mobile phones & Moldovan et al., 2015 & $\mathrm{~B} 2 \mathrm{C}$ & produc \\
\hline & broadband internet & Park and Yoon, 2005 & $\mathrm{~B} 2 \mathrm{C}$ & service \\
\hline & Internet Protocol Television & Sawng et al., 2013 & $\mathrm{~B} 2 \mathrm{C}$ & product \\
\hline & internet services & Stafford, 2003 & $\mathrm{~B} 2 \mathrm{C}$ & service \\
\hline & microblogs & Svensson, 2014 & $\mathrm{~B} 2 \mathrm{C}$ & service \\
\hline & video players & Van Rijnsoever and Harmen Oppewal, 2012 & $\mathrm{~B} 2 \mathrm{C}$ & product \\
\hline & food processors; video cassette recorders; PCs & Venkatraman and Meera, 1991 & $\mathrm{~B} 2 \mathrm{C}$ & product \\
\hline medical, health, and & internet-based patient education programme & Anttila et al., 2011 & B2B & process \\
\hline \multirow[t]{15}{*}{ pharmaceutical } & clinical BRCA1/2 testing & Armstrong et al., 2003 & $\mathrm{~B} 2 \mathrm{C}$ & product \\
\hline & new drugs & Bourke and Roper, 2012 & B2B & product \\
\hline & HIV/AIDS Positive Living (a public health innovation) & Caldwell and Kleppe, 2010 & $\mathrm{~B} 2 \mathrm{~B}$ & service \\
\hline & health behavior innovation (internet-based diet diary) & Centola, 2011 & $\mathrm{~B} 2 \mathrm{C}$ & product \\
\hline & robot-assisted minimally invasive surgery & Cundy et al., 2014 & B2B & process \\
\hline & contingency management & Hartzler and Rabun, 2013 & $\mathrm{~B} 2 \mathrm{~B}$ & process \\
\hline & new drugs (celecoxib, alendronate, clopidogrel, pantoprazole) & Kozyrskyj et al., 2007 & B2B & product \\
\hline & new drugs & Lublóy, 2014 & B2B & product \\
\hline & adjuvant radiotherapy (brachytherapy) & Pollack et al., 2015 & B2B & product \\
\hline & QIRC strategy & Simunovic et al., 2013 & $\mathrm{~B} 2 \mathrm{~B}$ & process \\
\hline & drug use & Van Havere et al., 2012 & $\mathrm{~B} 2 \mathrm{C}$ & product \\
\hline & point-of-care ultrasonography & Woo et al., 2013 & $\mathrm{~B} 2 \mathrm{~B}$ & service \\
\hline & digital technologies (dental practice) & van der Zande et al., 2013 & $\mathrm{~B} 2 \mathrm{~B}$ & process \\
\hline & instructional technology (medical faculty teaching) & Zayim et al., 2006 & B2B & process \\
\hline & e-appointment scheduling service (e-health) & Zhang et al., 2015 & $\mathrm{~B} 2 \mathrm{C}$ & service \\
\hline \multirow[t]{8}{*}{ agriculture and farming } & maize & Boz and Akbay, 2005 & B2B & product \\
\hline & conservation cropping system & Forte'-Gardner et al., 2004 & $\mathrm{~B} 2 \mathrm{~B}$ & process \\
\hline & organic drystock production & Läpple and Van Rensburg, 2011 & B2B & process \\
\hline & organic farming & Padel, 2001 & $\mathrm{~B} 2 \mathrm{~B}$ & process \\
\hline & organic farming & Parra-Lopez et al., 2007 & $\mathrm{~B} 2 \mathrm{~B}$ & process \\
\hline & conservation practices & Upadhyay et al., 2002 & B2B & process \\
\hline & grid soil sampling; yield monitoring; remote sensing process & Watcharaanantapong et al., 2014 & $\mathrm{~B} 2 \mathrm{~B}$ & process \\
\hline & water trade & Wheeler et al., 2009 & $\mathrm{~B} 2 \mathrm{~B}$ & process \\
\hline energy production (industrial & solar power & Faiers and Neame, 2006 & $\mathrm{~B} 2 \mathrm{C}$ & product \\
\hline \multirow[t]{5}{*}{ and home) } & solar power & Faiers et al., 2007 & $\mathrm{~B} 2 \mathrm{C}$ & product \\
\hline & IHS (Innovative Heating Systems) & Mahapatra and Gustavsson. 2008 & $\mathrm{~B} 2 \mathrm{C}$ & product \\
\hline & small-scale sustainable energy solutions & Nygrén et al., 2015 & $\mathrm{~B} 2 \mathrm{C}$ & product \\
\hline & solar heaters & Ornetzeder, 2001 & $\mathrm{~B} 2 \mathrm{C}$ & produc \\
\hline & wood pellet heating & Sopha et al., 2011 & $\mathrm{~B} 2 \mathrm{C}$ & product \\
\hline automotive and & alternative fuel vehicle & Jansson et al., 2011 & $\mathrm{~B} 2 \mathrm{C}$ & product \\
\hline \multirow[t]{4}{*}{ transportation } & plug-in electric vehicles & Namdeo et al., 2014 & $\mathrm{~B} 2 \mathrm{C}$ & product \\
\hline & electric vehicles & Peters and Dütschke, 2014 & $\mathrm{~B} 2 \mathrm{C}$ & product \\
\hline & electric vehicles & Plötz et al., 2014 & $\mathrm{~B} 2 \mathrm{C}$ & product \\
\hline & electric vehicles (e-bike \& e-scooter) & Seebauer, 2015 & $\mathrm{~B} 2 \mathrm{C}$ & product \\
\hline \multirow[t]{3}{*}{ consumables (food) } & table wine & Rossow, 2005 & $\mathrm{~B} 2 \mathrm{C}$ & product \\
\hline & ecolabel & Thøgersen, 2010 & $\mathrm{~B} 2 \mathrm{C}$ & product \\
\hline & MyPlate & Wansink and Kranz, 2013 & $\mathrm{~B} 2 \mathrm{C}$ & service \\
\hline crafts & pottery & Eerkens and Lipo, 2014 & $\mathrm{~B} 2 \mathrm{C}$ & product \\
\hline
\end{tabular}


Our second grouping strategy employed an inductive approach to allow the emergence of a generic set of variable categories. Repeated iterations between the data and the diffusion of innovations theory led us to propose four groups of variables sociodemographic, personality, behavioural, and resources - which essentially define the characteristics of the adopting unit, in other words, the individual. These emergent groups align with, and at the same time extend, Rogers's (1962) original set of characteristics of the decision making unit.

In Table 2 we firstly summarise the sociodemographic variables most commonly employed by scholars - age, education level, income, and gender.

Table 2 Sociodemographic variables explaining the diffusion of innovations

\begin{tabular}{|c|c|c|c|c|c|}
\hline \multirow{2}{*}{$\begin{array}{l}\text { Characteristics of } \\
\text { adopting unit } \\
\text { sociodemographic }\end{array}$} & \multirow{2}{*}{$\begin{array}{l}\text { Variable } \\
\text { age }\end{array}$} & \multirow{2}{*}{$\begin{array}{c}\begin{array}{c}\text { No. of } \\
\text { studies }\end{array} \\
24\end{array}$} & \multicolumn{3}{|c|}{$\begin{array}{c}\text { Findings } \\
\text { (positive influence on diffusion) }\end{array}$} \\
\hline & & & & & \\
\hline & & & agriculture and farming (5) & $\begin{array}{l}\text { young (1) } \\
\text { old (2) }\end{array}$ & no effect (2) \\
\hline & & & automotive and transportation (2) & middle age (2) & \\
\hline & & & consumables (food) (1) & - & no effect (1) \\
\hline & & & electronics, IT, internet, and social media (6) & $\begin{array}{l}\text { young (5) } \\
\text { old (1) }\end{array}$ & \\
\hline & & & energy production (industrial and home) (3) & young (3) & \\
\hline & & & medical, health, and pharmaceutical (7) & $\begin{array}{l}\text { young (3) } \\
\text { old (1) }\end{array}$ & no effect (3) \\
\hline & educational level & 19 & & & \\
\hline & & & agriculture and farming (5) & $\begin{array}{l}\text { high (3) } \\
\text { low (1) }\end{array}$ & no effect (1) \\
\hline & & & automotive and transportation (2) & high (1) & no effect (1) \\
\hline & & & consumables (food) (1) & - & no effect (1) \\
\hline & & & electronics, IT, internet, and social media (6) & $\begin{array}{l}\text { high (5) } \\
\text { low (1) }\end{array}$ & \\
\hline & & & energy production (industrial and home) (2) & $\begin{array}{l}\text { high (1) } \\
\text { low (1) }\end{array}$ & \\
\hline & & & medical, health, and pharmaceutical ( 3 ) & high (2) & no effect (1) \\
\hline & income & 11 & & & \\
\hline & & & agriculture and farming (2) & high (2) & \\
\hline & & & electronics, IT, internet, and social media (5) & high (3) & no effect (2) \\
\hline & & & energy production (industrial and home) (3) & $\begin{array}{l}\text { high (1) } \\
\text { medium (1) } \\
\text { low (1) }\end{array}$ & \\
\hline & & & medical, health, and pharmaceutical (1) & high (1) & \\
\hline & gender & 11 & & & \\
\hline & & & agriculture and farming (1) & female (1) & \\
\hline & & & automotive and transportation (2) & male (2) & \\
\hline & & & consumables (food) (1) & female (1) & \\
\hline & & & electronics, IT, internet, and social media (4) & male (3) & no effect (1) \\
\hline & & & medical, health, and pharmaceutical (3) & $\begin{array}{l}\text { male (1) } \\
\text { female (1) }\end{array}$ & no effect (1) \\
\hline
\end{tabular}

Among the sociodemographic variables, age $(n=24)$ and education level $(n=19)$ have been the most prominently studied independent variables to understand adoption of 
innovations by innovators and early adopters. The table also indicates that the four variables have been explored across various empirical contexts. Nevertheless, there does not appear to be consensus on the causal influence of these variables on adoption behaviour in general, as well as within any particular empirical context. For example, the variable 'age' has been employed in studying the diffusion of agriculture and farming innovations on five occasions. In one of the studies the authors have found younger individuals to be more likely to adopt the innovation (organic drystock production) while in two studies older individuals to be more likely to adopt the innovations (organic farming and water trade, respectively). Meanwhile two other studies report 'age' to have no influence on the adoption of innovations (maize and conservation practices, respectively). Similar inconsistencies can be observed for the other empirical settings where the variable 'age' has been examined, as well as the other sociodemographic variables listed in Table 2. Overall, these findings question the relevance of sociodemographic descriptors of the social system (i.e. individuals) as determinants of innovation adoption.

In Table 3 we summarise the personality variables employed by scholars in their studies, which refer to the intrinsic descriptors of the individual adopter. 
Table 3 Personality variables explaining the diffusion of innovations

\begin{tabular}{|c|c|c|c|c|c|}
\hline $\begin{array}{l}\text { Characteristics of } \\
\text { adopting unit }\end{array}$ & Variable & $\begin{array}{l}\text { No. of } \\
\text { studies }\end{array}$ & $\begin{array}{c}\text { Findings } \\
\text { (positive influence on }\end{array}$ & liffusion) & \\
\hline$\overline{\text { Personality }}$ & outward focus ${ }^{1}$ & & & & \\
\hline & environmental concern & 7 & agriculture and farming (2) & high (2) & \\
\hline & & & automotive and transportation (2) & high (2) & \\
\hline & & & consumables (food) (1) & high (1) & \\
\hline & & & energy production (industrial and home) (2) & $\operatorname{high}(1)$ & no effect (1) \\
\hline & trust in organization & 2 & consumables (food) (1) & $\operatorname{high}(1)$ & \\
\hline & & & electronics, IT, internet, and social media (1) & high (1) & \\
\hline & technology orientation ${ }^{2}$ & & & & \\
\hline & technophilia & 4 & automotive and transportation (2) & high (1) & no effect (1) \\
\hline & & & energy production (industrial and home) (1) & high (1) & \\
\hline & & & electronics, IT, internet, and social media (1) & $\operatorname{high}(1)$ & \\
\hline & technology use attitude & 3 & electronics, IT, internet, and social media (1) & positive (1) & \\
\hline & & & medical, health, and pharmaceutical (2) & positive (1) & no effect (1) \\
\hline & technological anxiety & 1 & electronics, IT, internet, and social media (1) & low (1) & \\
\hline & innovativess & 7 & consumables (food) (1) & $\operatorname{high}(1)$ & \\
\hline & & & electronics, IT, internet, and social media (4) & high (4) & \\
\hline & & & medical, health, and pharmaceutical (2) & high (2) & \\
\hline & economic values ${ }^{3}$ & & & & \\
\hline & profit orientation & 2 & agriculture and farming (2) & low (2) & \\
\hline & saving consciousness & 2 & electronics, IT, internet, and social media (1) & - & no effect (1) \\
\hline & & & energy production (industrial and home) (1) & $\operatorname{high}(1)$ & \\
\hline & willingness to pay & 1 & automotive and transportation (1) & high (1) & \\
\hline & inward focus ${ }^{4}$ & & & & \\
\hline & self-efficacy & 3 & electronics, IT, internet, and social media (2) & high (1) & no effect (1) \\
\hline & & & medical, health, and pharmaceutical (1) & high (1) & \\
\hline & market mavenism & 1 & electronics, IT, internet, and social media (2) & high (1) & \\
\hline & novelty ${ }^{5}$ & & & & \\
\hline & risk attitude & 2 & agriculture and farming (2) & $\operatorname{low}(1)$ & no effect (1) \\
\hline & novelty seeking & 1 & electronics, IT, internet, and social media (1) & high (1) & \\
\hline & non-traditionalism & 1 & electronics, IT, internet, and social media (1) & high (1) & \\
\hline & cosmopoliteness & 4 & agriculture and farming (2) & $\begin{array}{l}\text { more (1) } \\
\text { less (1) }\end{array}$ & \\
\hline & & & electronics, IT, internet, and social media (1) & - & no effect (1) \\
\hline & & & medical, health, and pharmaceutical (3) & - & no effect (1) \\
\hline & opinion leadership & 3 & agriculture and farming (1) & high (1) & \\
\hline & & & automotive and transportation (1) & high (1) & \\
\hline & & & electronics, IT, internet, and social media (1) & high (1) & \\
\hline & communication needs & 3 & electronics, IT, internet, and social media (2) & high (1) & no effect (1) \\
\hline & & & energy production (industrial and home) (1) & high (1) & \\
\hline
\end{tabular}

${ }^{1}$ variables 'community consciousness' and 'future orientation' have no effect

2variables 'willingness to adopt other innovations' and 'craftsman' have no effect

${ }^{3}$ variable 'cost orientation' has no effect

${ }^{4}$ variables 'subjective norms', 'health consciousness', 'egoistic values', 'altruistic values', 'voluntariness', and 'positive attitude' have no effect

5variables 'adventurous' and 'outgoing' have no effect

By and large, the personality related variables show more consistency than sociodemographic variables. While we are unable to make statistically confident conclusions, we see that outward focus variables (environmental concern and trust in organisation) are mostly consistent in the way they influence adoption by innovators and 
early adopters. Technology orientation variables (technophilia, technology use attitude, and technology anxiety) as well as inward focus variables (self-efficacy and market mavenism - being knowledgeable about the market) illustrate similar consistencies. The table underlines most notable consistency for the 'innovativeness' variable, with all studies (in three different empirical settings) showing that a high level of innovativeness as a personality trait will lead to innovation adoption. Early adopters of an innovation are also shown to display high level of opinion leadership, which is necessary for the dissemination of that innovation to larger market segments. Overall, our meta-analysis gives some confidence for the explanatory power of most personality attributes in the adoption behaviour of innovators and early adopters, although 'cosmopoliteness' (being open to new ideas and information) appears to be a surprising exemption from this list.

Table 4 summarises the behavioural variables employed in studies, in other words, the variables that describe what the individuals do leading up to the adoption of an innovation.

Table 4 Behavioural variables explaining the diffusion of innovations

\begin{tabular}{|c|c|c|c|c|c|}
\hline \multirow{2}{*}{$\begin{array}{l}\text { Characteristics of } \\
\text { adopting unit } \\
\text { Behavioral }\end{array}$} & Variable & $\begin{array}{l}\text { No. of } \\
\text { studies }\end{array}$ & \multicolumn{3}{|c|}{$\begin{array}{c}\text { Findings } \\
\text { (positive influence on diffusion) }\end{array}$} \\
\hline & information use & & & & \\
\hline & \multirow[t]{2}{*}{ information search and gathering } & \multirow[t]{2}{*}{3} & agriculture and farming (1) & \multicolumn{2}{|l|}{ more (1) } \\
\hline & & & energy production (industrial and home) (2) & \multicolumn{2}{|l|}{ more (2) } \\
\hline & use of extension personnel/service & 1 & agriculture and farming (1) & \multicolumn{2}{|l|}{ more (1) } \\
\hline & frequency of consultation & 1 & agriculture and farming (1) & \multicolumn{2}{|l|}{ less (1) } \\
\hline & deliberation and social comparison & 1 & energy production (industrial and home) (1) & \multicolumn{2}{|l|}{ less (1) } \\
\hline & \multicolumn{5}{|l|}{ media use } \\
\hline & \multirow[t]{2}{*}{ reading books and printed materials } & \multirow[t]{2}{*}{4} & agriculture and farming (3) & less (2) & no effect (1) \\
\hline & & & electronics, IT, internet, and social media (1) & \multicolumn{2}{|l|}{ more (1) } \\
\hline & use of general media & 1 & energy production (industrial and home) (1) & \multicolumn{2}{|l|}{ more (1) } \\
\hline & \multicolumn{5}{|l|}{ technology use $\mathrm{e}^{1}$} \\
\hline & use of ICT tools & 1 & electronics, IT, internet, and social media (1) & \multicolumn{2}{|l|}{ more (1) } \\
\hline & use of technology & 1 & medical, health, and pharmaceutical (1) & \multicolumn{2}{|l|}{ more (1) } \\
\hline & variety of use & 1 & electronics, IT, internet, and social media (1) & \multicolumn{2}{|l|}{ more (1) } \\
\hline & rate of use & 1 & electronics, IT, internet, and social media (1) & \multicolumn{2}{|l|}{ more (1) } \\
\hline & information sharing & 1 & electronics, IT, internet, and social media (1) & \multicolumn{2}{|l|}{ more (1) } \\
\hline
\end{tabular}

${ }^{1}$ variables 'use of internet', 'use of television', 'use of radio', and 'computer use frequency' have no effect

The majority of the behavioural traits examined in the literature encompass the individuals' use of information, media, and technology. The table suggests that the more innovators and early adopters use technology in their lives (i.e. use of ICT tools, use of technology (in general), variety of use, and rate of use) the more likely they will adopt innovations. How individuals use information and the media, however, do not confidently inform about the likelihood of innovation adoption. For example, two studies of agricultural and farming innovations (organic drystock production and organic farming) underscore that innovators and early adopters read less books and printed materials than later adopters, while the diffusion of e-book readers in the electronics, IT, internet, and social media context suggests the contrasting effect. At closer inspection, we see similar contradictions amongst the 'information use' variables. For instance, while individuals adopting Innovative Heating Systems in the energy production context have been shown 
to engage more in information search and gathering activities, adopters of wood pallet heating (in the same context) have been reported to delve less into deliberation and social comparison. These findings appear to contradict one another given that the latter is arguably another mode of information gathering. As a result, besides technology use variables, other behavioural attributes of individuals may not be accurate predictors of innovators' and early adopters' innovation adoption behaviour.

And finally in Table 5 we summarise the resource variables employed by scholars, in other words, the variables that describe what the individuals have in possession, and which may facilitate the adoption of innovations. 
Table 5 Resource variables explaining the diffusion of innovations

\begin{tabular}{|c|c|c|c|c|c|}
\hline $\begin{array}{l}\text { Characteristics of } \\
\text { adopting unit }\end{array}$ & Variable & $\begin{array}{l}\text { No. of } \\
\text { studies }\end{array}$ & $\begin{array}{c}\text { Findings } \\
\text { (positive influence on dif }\end{array}$ & usion) & \\
\hline Resources & prior experience & & & & \\
\hline & adoption of similar technology & 2 & energy production (industrial and home) (1) & more (1) & \\
\hline & & & medical, health, and pharmaceutical (1) & more (1) & \\
\hline & product experience & 2 & agriculture and farming (1) & more (1) & \\
\hline & & & electronics, IT, internet, and social media (1) & $\operatorname{good}(1)$ & \\
\hline & vocational experience & 2 & agriculture and farming (1) & less (1) & \\
\hline & & & electronics, IT, internet, and social media (1) & less (1) & \\
\hline & adoption of previous generation & 1 & electronics, IT, internet, and social media (1) & more (1) & \\
\hline & technical skills ${ }^{1}$ & & & & \\
\hline & computer skills & 2 & electronics, IT, internet, and social media (1) & high (1) & \\
\hline & & & medical, health, and pharmaceutical (1) & - & no effect (1) \\
\hline & elearning skills & 1 & electronics, IT, internet, and social media (1) & high (1) & \\
\hline & pedagogical competence & 1 & electronics, IT, internet, and social media (1) & high (1) & \\
\hline & digital skills & 1 & medical, health, and pharmaceutical (1) & high (1) & \\
\hline & computer experience & 1 & medical, health, and pharmaceutical (1) & high (1) & \\
\hline & network ${ }^{2}$ & & & & \\
\hline & recommending peers & 3 & energy production (industrial and home) (2) & more (2) & \\
\hline & & & medical, health, and pharmaceutical (1) & more (1) & \\
\hline & informal sources of information & 2 & agriculture and farming (1) & more (1) & \\
\hline & & & energy production (industrial and home) (1) & more (1) & \\
\hline & contact with credible people & 1 & medical, health, and pharmaceutical (1) & more (1) & \\
\hline & knowledge & & & & \\
\hline & general knowledge & 1 & consumables (food) (1) & more (1) & \\
\hline & subjective knowledge & 1 & consumables (food) (1) & more (1) & \\
\hline & knowledge of supporting systems & 1 & agriculture and farming (1) & more (1) & \\
\hline & awareness of innovation & 1 & medical, health, and pharmaceutical (1) & more (1) & \\
\hline & access to use & 2 & electronics, IT, internet, and social media (1) & more (1) & \\
\hline & & & medical, health, and pharmaceutical (1) & - & no effect (1) \\
\hline
\end{tabular}

1variable 'internet skills' has no effect

'variable 'knowledge of other adopters' has no effect

From the table we observe that resource variables are consistent predictors of the adoption decisions of innovators and early adopters. First, individuals' prior experiences (i.e. with similar technologies, with the innovation in question, with an occupation that relates to the innovation, and earlier generations of the innovation) all serve to motivate the adoption of the innovation. These findings are consistent for different empirical contexts as well. Interestingly, we see that individuals are more likely to adopt an innovation when they have been employed in the vocational setting for shorter time, possibly explained by their openness to new ideas. Second, the high level of technical skills of innovators and early adopters (e.g. their computer, e-learning, digital skills, as well as experience with computers and work related competences) appear to have a positive effect on their innovation adoption decisions. The table thirdly shows that individuals access resources exogenous to themselves, namely, from their networks. Hence, innovators and early adopters are more likely to adopt innovations when they have more peers recommending the innovation, when they can access informal sources of 
information, and when they have contact with credible people. And finally, individuals that have more knowledge (whether this is general, subjective, about supporting systems, or about the innovation itself) are more likely to adopt the innovation. This is not a surprising finding and reaffirms the centrality of knowledge and communication channels as underlined by Rogers in his original framework.

Collectively, the results of our meta-analysis lead us to propose a conceptual model that relates the variables that can positively influence the innovation adoption decisions of innovators and early adopters (see Figure 1).

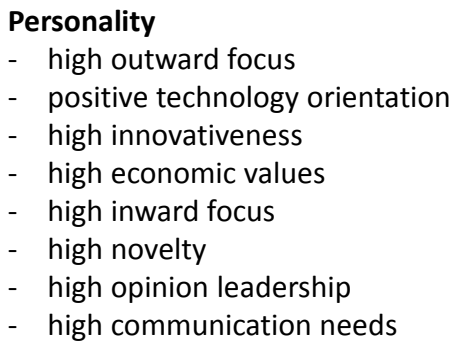

\section{Behavioral}

more technology use

\section{Resources}

- more prior experience

high technical skills

more network

more knowledge

Figure 1 Conceptual model of variables that can positively influence innovation adoption.

\section{Discussion and Conclusions}

Although innovators and early adopters account for less than $20 \%$ of potential adopters, they are very important in the diffusion process of innovations. This study commenced by reviewing the body of literature prior to 1995, and, in turn, used a systematic review process to study the literature after 1995 to identify the variables that can characterise innovators and early adopters. Our paper specifically focused on the following research questions:

- What are the characteristics of innovators and early adopters?

- How do post 1995 empirical studies relate to the work done before 1995? 
In answering these questions, our exploration suggests that the characteristics of innovators and early adopters proposed by scholars prior to 1995 are roughly the same as those employed in empirical work after 1995. Indeed, some broad categories of variables - such as sociodemographic and personality traits - have remained central to this field of research over time. Nevertheless, our meta-analysis of the literature post-1995 suggests that some of the specific variables that fall within these broad categories (e.g. age, education level, and gender) are not consistent descriptors of innovators and early adopters and should therefore be omitted from forecasting exercises. Interestingly, the inconsistency of these independent variables have been underlined in earlier, seminal contributions, and yet, as our study shows, scholars continue to employ them in contemporary empirical work.

By contrast, other specific variables do show consistency in their description of innovators and early adopters (e.g. innovativeness, technology orientation, and economic values). This finding suggests that businesses can benefit from understanding a personality trait such as innovativeness, which can be assessed either as the time of adoption of the specific product innovation, or the count of the number of products in a specific category already adopted by an individual.

The review of the post-1995 literature also underscored the relevance of resource variables, in other words, what individuals have in possession that positively influences their decision to adopt an innovation. Our findings indicate that businesses aiming to launch new products and services should target individuals that possess more prior experience, have high technical skills and a strong social network. At the same time, businesses should spend effort in enhancing the potential adopters' knowledge about the new product or service.

\subsection{Scientific and managerial implications}

The domain-specific nature of innovator and early adopter characteristics

Our findings show that innovator characteristics vary per product category, an issue already highlighted in overviews in the mid-1990s but which continues to be emphasized in recent research, now more than 50 years after the emergence of this research strand. In fact, given that the variables that determine innovators and early adopters can vary from context to context, we observe that some scholars induce a selection-bias in their studies by determining, a priori, the population of innovators and early adopters based on a set of variables and their values as prescribed by Rogers. We argue that if these characteristics are product-category specific then we would expect that the specific characteristics (with a direct relationship to the product category to which the innovation belongs) have a stronger relationship with early adoption than the generic characteristics.

The tendency that innovator characteristics depend on the context has raised scientific interest, and is sometimes referred to as the domain-specific nature of innovator characteristics (Holak, 1988; Engel et al., 1990). Holak (1988) suggests that a continuum can be distinguished, ranging from generic innovator characteristics (e.g. sociodemographic characteristics) to more domain-specific characteristics (e.g. the possession and use of advanced telecommunication products and services as predictor of yet another innovation in that domain). The relationship between generic characteristics and adoption have been found to vary across domains, whereas specific characteristics have been found to have a stronger relationship with adoption in the domain to which the 
characteristics refer, as we might anticipate. Furthermore, Holak (1988) shows that potential customer evaluations of the innovation, particularly in the form of the customers' perception of innovation attributes (Holak and Lehman, 1990), are stronger related to adoption than both the specific and generic innovator characteristics.

This finding has important managerial implications. We can see an interesting tradeoff: the more generic innovator and early adopter characteristics are readily available to distinguish segments, from the perspective of companies commercializing an innovation, yet the more specific characteristics, especially the perceptions of potential customers regarding the innovation, are more predictive for adoption. In practice, this would call for a step-wise approach in which rough initial segments of potential innovators and early adopters are based on segmentation using generic and specific characteristics, after which a subset of potential adopters are requested to evaluate the innovation, or an early concept of it, to check and further refine the segment of innovators and early adopters on which the market introduction campaign could focus. This is especially useful if one takes into account that radical innovations most often attract very small and specific segment of customers that, if not selected properly, would be lost in the larger population of customers (Tauber, 1974; Ortt et al., 2007). The results of our review do fit into the first step of this approach of distinguishing the segment of early adopters and innovators.

\section{Organisational versus individual decision-making}

Methodologically the articles in our review focused on the characteristics of individual adopters, be it innovators or early adopters. We have thus explored innovator and early adopter characteristics in many studies across sectors (see Table1) and focused on personality, behavioural aspects, and resources of individual adopters. The studies in our overview nevertheless do include B2B settings. In such a setting, customers can be larger corporations, in which a type of decision making can be expected prior to adoption that involves individuals from different departments and with different disciplinary backgrounds. In these cases decision making prior to adoption becomes an entirely different process in which, most notably, decision-makers and adopters are often not the same individuals. This situation calls for an entirely different approach including generic and specific characteristics of innovative organisations as well as adapted evaluation criteria and adoption process stages, as compared to cases involving individual decision makers that adopt themselves. A review of the characteristics of such organisations that are innovators and early adopters is undoubtedly highly interesting, but it requires a separate research project.

Almost all of the B2B studies included in our overview were either in the agricultural sector or in a medical, health of pharmaceutical setting. In these settings, most often a farmer or doctor is the individual decision maker. In fact, diffusion research did start with exploring farmer's characteristics adopting various innovations (Rogers, 1958). We checked the articles and found that the studies in B2B contexts deliberately asked individuals to evaluate their adoption decisions. So, both the specific industrial setting (agricultural and medical) and the methodology of the articles (focusing on individuals' characteristics) justify the combination of cases from a B2B and B2C setting.

\section{The pro-innovation bias}

Rogers discusses the pro-innovation bias in his seminal work. "The pro-innovation bias is the implication in diffusion research that an innovation should be diffused and adopted by all members of a social system, that is should be diffused more rapidly, and 
that the innovation should be neither re-invented nor rejected.” (Rogers, 2003, p. 106). From a societal perspective, this bias is very dangerous if the innovation is not so beneficial to all. Many studies have indeed explored the accidents and detrimental effects of innovations (e.g. Perrow, 2011; Florman, 2000).

A first scientific consequence of the pro-innovation bias is that we know much more about innovators than rejecters. In fact, in many diffusion articles the innovators come first and the laggards and complete non-adopters or rejecters are last. This implies a bias towards innovators and a neglect of the rejecters. In contrast, Labay and Kinnear (1981) show that early rejecters and innovators have remarkably similar characteristics. They have in common that they are the first to get to know about an innovation. The managerial implication of this similarity in characteristics of innovators and early rejecters, is that the size of the segment of innovators and early adopters can be overestimated if these characteristics were applied to define this segment.

A second scientific consequence of the pro-innovation bias, especially the part that an innovation should not be re-invented, is that the trial-and-error process of product improvement and customer segment exploration is completely ignored. Diffusion research seems to imply that diffusion starts slowly yet smoothly, in practice that is hardly the case. As a result some authors have suggested to distinguish a separate phase prior to the start of the large-scale diffusion (Moore, 2002; Ortt, 2004). This phase before large-scale diffusion is sometimes found to be long, spanning a decade or more on average (Ortt, 2010). Managerially this phase, which is almost completely ignored in diffusion research, has important implications: it means that innovations have to be improved and repositioned before successful diffusion starts. Innovators in this stage may have the character of a lead user that is actively involved in improving the innovation rather than just adopting and using it.

\section{The adopters are part of a larger system}

Overall, our review shows that other variables that were not necessarily considered in Rogers's work, can explain innovativeness in different contexts. Besides personality, behavioural, and resource variables that pertain to the individual adopter, factors exogenous to the adopter, including supplier reputation, the supplier's resource commitments, and the availability of complementary products and services can also play a role in the speed with which an innovation is adopted. Our findings therefore suggest that new perspectives are necessary to improve academic understanding of the behavioural characteristics for those individuals that are first to adopt innovations.

\section{Future research}

Two of the methodological issues seem, still now, to represent a serious gap in the literature. Firstly, some studies indicate that early adopters and early rejecters (the ones that early on decide not to adopt an innovation) may have similar characteristics, but require further research to verify this proposition and understand the nature of these similarities. This is an important issue that could render the notion of innovator characteristics futile if not addressed properly.

Another line of work that requires attention is the notion that innovativeness and opinion leadership are distinctly different. As Engel et al. (1990, p.698) assert, "[w]hen a social system's norms favour change, opinion leaders are more innovative, but when the 
norms do not favour change, opinion leaders are not especially innovative.” This suggests that opinion leadership is contextual, and further, that if some innovators do scare subsequent groups of adopters away with their deviant behaviour then the smooth diffusion curve would collapse. It is important therefore to carefully distinguish between two situations: (1) when innovators and early adopters have opinion leader characteristics and thereby seem to invite subsequent adopter groups, versus (2) when innovators and early adopters are distinctly different from opinion leaders and scare away subsequent adopter groups

\section{References and Notes}

Anttila, M., Välimäki, M., Koivunen, M., Luukkaala, T., Kaila, M., Pitkänen, A. \& Kontio, R. (2011). Adoption of an Internet-based patient education programme in psychiatric hospitals. Journal of Psychiatric and Mental Health Nursing, 18, 914 23.

Armstrong, K., Weiner, J. Weber, B., \& Ash, D.A. (2003). Early adoption of BRCA1/2 testing: Who and why. Genetics in Medicine, 5(2), 92-98.

Atkin, D.J., Jeffres, L.W., \& Nueundorf, K.A. (1998). Understanding internet adoption as telecommunications behavior. Journal of Broadcasting \& Electronic Media, 42(4), 475-490.

Berger, T. (2001). Agent-based spatial models applied to agriculture: a simulation tool for technology diffusion, resource use changes and policy analysis. Agricultural Economics, 25(2-3), 245-60.

Bergstrom, A. \& Hoglund, L. (2014). A national survey of early adopters of e-book reading in Sweden. Information Research, 19(2).

Berwick, D. M. (2003). Disseminating innovations in health care. Journal of the American Medical Association, 289(15), 1969-1975.

Blackburn, H. (2011). Millennials and the adoption of new technologies in libraries through the diffusion of innovations process. Library Hi Tech, 29(4), 663-677.

Bourke, J. \& Roper, S. (2012). In with the new: The determinants of prescribing innovation by general practitioners in Ireland. The European Journal of Health Economics, 13(4), 393-407.

Boyd, T.C. \& Mason, C.H. (1999). The link between attractiveness of "extrabrand" attributes and the adoption of innovations. Academy of Marketing Science Journal, 27(3), 306-319.

Boz, I. \& Akbay, C. (2005). Factors influencing the adoption of maize in Kahramanmaras province of Turkey. Agricultural Economics, 33, 431-440.

Caldwell, M. \& Kleppe, I. (2010) "Early Adopters in the Diffusion of an Hiv/Aids Public Health Innovation in a Developing Country", in NA - Advances in Consumer Research, Vol. 37, eds. Margaret C. Campbell, Jeff Inman, and Rik Pieters, Duluth, MN: Association for Consumer Research, Pages: 326-332.

Centola, D. (2011). An experimental study of homophily in the adoption of health behavior. Science, 334, 1269-1272.

Chiyangwa, T.B. \& Alexander, P.M. (2015). Rapidly co-evolving technology adoption and diffusion models. Telematics and Informatics, 33, 56-76.

Cho, Y. and Koo, Y. (2012). Investigation of the effect of secondary market on the diffusion of innovation. Technological Forecasting \& Social Change, 79, 13621371. 
Cundy, T.P., Marcus, H.J., Hughes-Hallett, A., Najmaldin, A.S., Yang, G.-Z., \& Darzi, A. (2014). International attitudes of early adopters to current and future robotic technologies in pediatric surgery. Journal of Pediatric Surgery, 49, 1522-1526.

Eerkens, J. W. \& Lipo, C. P. (2014). A tale of two technologies: Prehistoric diffusion of pottery innovations among hunter-gatherers. Journal of Anthropological Archaeology, 35, 23-31.

Engel, J. F., Blackwell, R. D. \& Miniard, P. W. (1990). Consumer Behaviour. Hinsdale (IL), The Dryden Press.

Evanschitzky, H., Iyer, G.R., Pillai, K.G., Kenning, P., \& Schütte, R. (2015). Consumer trial, continuous use, and economic benefits of a retail service innovation: The case of the personal shopping assistant. Journal of Product Innovation Management, 32(3), 459-475.

Faiers, A. \& Neame, C. (2006). Consumer attitudes towards domestic solar power systems. Energy Policy, 34(14), 1797-1806.

Faiers, A., Neame, C., \& Cook, M. (2007). The adoption of domestic solar-power systems: Do consumers assess product attributes in a stepwise process? Energy Policy, 35, 3418-3423.

Florman, S. C. (2000). Technology and the Tragic View. In: Technology and the Future. A. H. Teich. Boston, New York, Bedford/St. Martin's, 50-58.

Forte'-Gardner, O., Young, F.L., Dillman, D.A., \& Carroll, M.S. (2004). Increasing the effectiveness of technology transfer for conservation cropping systems through research and field design. Renewable Agriculture and Food Systems, 19(4), 199209.

Foxall, G. R., Goldsmith, R. E. (1994). Consumer Psychology for Marketing. London, Routledge.

Griliches, Z. (1957). Hybrid corn: An exploration in the economics of technological change. Econometrica, 25(4), 501-22.

Hart, C. (1998). Doing a literature review: Releasing the social science research imagination. Sage.

Hartzler, B. \& Rabun, C. (2013). Community treatment adoption of contingency management: A conceptual profile of U.S. clinics based on innovativeness of executive staff. International Journal of Drug Policy, 24, 333-341.

Holak, S. L. (1988). Determinants of innovative durables adoption an empirical study with implications for early product screening. Journal of Product Innovation Management, 5(1), 50-69.

Holak, S. L. \& Lehmann, D.R. (1990). Purchase intentions and the dimensions of innovation: An exploratory model. Journal of Product Innovation Management, 7(1), 59-73.

Jansson, J., Marell, A., \& Nordlund, A. (2011). Exploring consumer adoption of a high involvement eco-innovation using value-belief-norm theory. Journal of Consumer Behaviour, 10, 51-60.

Jeyaraj, A., Rottman, J. W. \& Lacity, M. C. (2006). A review of the predictors, linkages, and biases in IT innovation adoption research. Journal of Information Technology, 21(1), 1-23.

Jin, C.-H. (2013). The effects of individual innovativeness on users' adoption of Internet content filtering software and attitudes toward children's Internet use. Computers in Human Behavior, 29, 1904-1916.

Kah, J.A., Vogt, C.A., \& MacKay, K. (2006). Understanding travel information search behaviors by levels of information technology adoption. Proceedings of the 2006 Northeastern Recreation Research Symposium, 104-109.

Kauffman, R.J. \& Techatassanasoontorn, A.A. (2009). Understanding early diffusion of digital wireless phones. Telecommunications Policy, 33, 432-450. 
Kavak, B. \& Demirsoy, C. (2009). Identification of adopter categories for online banking in Turkey. The Service Industries Journal, 29(8), 1037-1051.

Kozyrskyj, A., Raymond, C., \& Racher, A. (2007). Characterizing early prescribers of newly marketed drugs in Canada: A population-based study. European Journal of Clinical Pharmacology, 63, 597-604.

Labay, D.G. and Kinnear, Th.C. (1981) Exploring the consumer decision process in the adoption of solar energy systems. The Journal of Consumer Research, 8(3), 271278.

Lee, S.-Y. (2014). Examining the factors that influence early adopters' smartphone adoption: The case of college students. Telematics and Informatics, 31, 308-318.

Lin, M.-S. \& Wu, F.-S. (2013). Identifying the determinants of broadband adoption by diffusion stage in OECD countries. Telecommunications Policy, 37, 241-251.

Loogma, K., Kruusvall, J., \& Ümarik, M. (2012). E-learning as innovation: Exploring innovativeness of the VET teachers' community in Estonia. Computers \& Education, 58, 808-817.

Lublóy, Á. (2014). Factors affecting the uptake of new medicines: A systematic literature review. BMC Health Services Research, 14, 1-25.

Läpple, D. \& Van Rensburg, T. (2011). Adoption of organic farming: Are there differences between early and late adoption? Ecological Economics, 70, 1406-1414.

Mahapatra, K. \& Gustavsson, L. (2008). An adopter-centric approach to analyze the diffusion patterns of innovative residential heating systems in Sweden. Energy Policy, 36(2), 577-90.

Moldovan, S., Steinhart, Y., \& Ofen, S. (2015). "Share and scare”: Solving the communication dilemma of early adopters with a high need for uniqueness. Journal of Consumer Psychology, 25(1), 1-14.

Moore, G. A. (2002). Crossing the Chasm. Marketing and Selling Disruptive Products to Mainstream Customers. New York, HarperCollins Publishers.

Namdeo, A., Tiwary, A., \& Dziurla, R. (2014). Spatial planning of public charging points using multi-dimensional analysis of early adopters of electric vehicles for a city region. Technological Forecasting and Social Change, 89, 188-200.

Nygrén, N.A, Kontio, P., Lyytimäki, J., Varho, V., \& Tapio, P. (2015). Early adopters boosting the diffusion of sustainable small-scale energy solutions. Renewable and Sustainable Energy Reviews, 46, 79-87.

Ornetzeder, M. (2001). Old technology and social innovations. Inside the Austrian success story on solar water heaters. Technology Analysis \& Strategic Management, 13(1), 105-115.

Ortt, J.R. \& Schoormans, J.P.L. (2004). The Pattern of Development and Diffusion of Breakthrough Communication Technologies, European Journal of Innovation Management 7(4), 292-302.

Ortt, R.J., Langley, D.J. \& Pals, N. (2007). Exploring the market for breakthrough technologies. Technological Forecasting and Social Change, 74(9), 1788-1804.

Ortt, J.R. (2010). Understanding the Pre-diffusion Phases. Gaining Momentum Managing the Diffusion of Innovations. J. Tidd. London, Imperial College Press: 47-80.

Padel, S. (2001). Conversion to organic farming: A typical example of the diffusion of an innovation? Sociologia Ruralis, 41(1), 40-61.

Park, S. \& Yoon, S.-H. (2005). Separating early-adopters from the majority: The case of broadband internet access in Korea. Technological Forecasting and Social Change, 72(3), 301-25.

Parra-Lopez, C., De-Haro-Giménez, T., \& Calatrava-Requena, J. (2007). Diffusion and adoption of organic farming in the southern Spanish olive groves. Journal of Sustainable Agriculture, 30(1), 105-51. 
Perrow, C. (2011). Normal accidents: Living with high risk technologies, Princeton University Press.

Peters, A. \& Dütschke, E. (2014). How do consumers perceive electric vehicles? A comparison of German consumer groups. Journal of Environmental Policy \& Planning, 16(3), 359-77.

Plötz, P., Schneider, U., Globisch, J., \& Dütschke, E. (2014). Who will buy electric vehicles? Identifying early adopters in Germany. Transportation Research Part A, 67, 96-109.

Pollack, C.E., Soulos, P.R., \& Gross, C.P. (2015). Physician's peer exposure and the adoption of a new cancer treatment modality. Cancer, Aug, 2799-2807.

Robertson, T. S. (1971). Innovative behavior and communication, Holt, Rinehart and Winston.

Rogers, E. M. (1958). Categorizing the adopters of agricultural practices, Rural Sociology, 23(4), 346-354.

Rogers, E. M. (1962). Diffusion of Innovations (1st ed.). New York, NY, Free Press.

Rogers, E.M., and Shoemaker, F. (1971) Diffusion of innovations. ( $2^{\text {nd }}$ ed.). New York, NY, Free Press.

Rogers, E. M. (1995). Diffusion of Innovations. (4th ed.). New York, NY, Free Press.

Rogers, E. M. (2003). Diffusion of Innovations. (5th ed.). New York, NY, Free Press.

Rossow, I. (2005). Trends in wine consumption in Norway: Is diffusion theory applicable? Advances in Health Economics and Health Services Research, 16, 215 28.

Sawng, Y.-W., Motohashi, K., \& Kim, G.-H. (2013). Comparative analysis of innovative diffusion in the high-tech markets of Japan and South Korea: A use-diffusion model approach. Service Business, 7(1), 143-66.

Seebauer, S. (2015). Why early adopters engage in interpersonal diffusion of technological innovations: An empirical study on electric bicycles and electric scooters. Transportation Research Part A, 78, 146-60.

Simunovic, M., Coates, A., Smith, A., Thabane, L., Goldsmith, C.H., \& Levine, M.N. (2013). Uptake of an innovation in surgery: Observations from the ClusterRandomized Quality Initiative in Rectal Cancer Trial. Canadian Journal of Surgery, 56(6), 415-21.

Sopha, B.M., Klöckner, C.A., \& Hertwich, E.G. (2011). Adopters and non-adopters of wood pellet heating in Norwegian households. Biomass and Bioenergy, 35, $652-$ 662.

Stafford, T.F. (2003). Differentiating between adopter categories in the uses and gratifications for internet services. IEEE Transactions on Engineering Management, 50(4), 427-35.

Svensson, M. (2014). Voice, power and connectivity in China’s microblogosphere: Digital divides on SinaWeibo. China Information, 28(2), 168-88.

Tauber, E. M. (1974). How market research discourages major innovation. Business Horizons, 17(3), 22-26.

Thøgersen, J., Haugaard, P., \& Olesen, A. 2010. Consumer responses to ccolabels. European Journal of Marketing, 44(11/12), 1787-1810.

Upadhyay, B.M., Young, D.L., Wang, H.H., \& Wandschneider, P. (2002). How do farmers who adopt multiple conservation practices differ from their neighbors? In Annual Meetings of the Western Agricultural Economics Association, Long Beach, CA.

Van Der Zande, M.M., Gorter, R.C., \& Wismeijer, D. (2013). Dental practitioners and a digital future: An initial exploration of barriers and incentives to adopting digital technologies. British Dental Journal, 215(11), 1-5. 
Van Havere, T., Lammertyn, J., Vanderplasschen, W., Bellis, M., Rosiers, J., \& Broekaert, E. (2012). Illicit drug use in the Flemish nightlife scene between 2003 and 2009. European Addiction Research, 18(4), 153-60.

Van Rijnsoever, F.J. \& Oppewal, H. (2012). Predicting early adoption of successive video player generations. Technological Forecasting and Social Change, 79(3), $558-569$.

Venkatraman, M.P. (1991). The impact of innovativeness and innovation type on adoption. Journal of Retailing, 67(1), 51-67.

Wansink, B. \& Kranz, S. 2013. Who's using MyPlate? Journal of Nutrition Education and Behavior, 45(6), 728-32.

Watcharaanantapong, P., Roberts, R.K., Lambert, D.M., Larson, J.A., Velandia, M., English, B.C., Rejesus, R.M., \& Wang, C. (2014). Timing of precision agriculture technology adoption in US cotton production. Precision Agriculture, 15(4), 427-46.

Wheeler, S., Bjornlund, H., Shanahan, M., \& Zuo, A. (2009). Who trades water allocations? Evidence of the characteristics of early adopters in the GoulburnMurray irrigation district, Australia 1998-1999. Agricultural Economics, 40, 631643.

Woo, M.Y., Frank, J.R., \& Lee, A.C. (2013). Point-of-Care Ultrasonography adoption in Canada: Using diffusion theory and the Evaluation Tool for Ultrasound Skills Development and Education (ETUDE). Canadian Journal of Emergency Medicine, 16(5), 245-51.

Zayim, N., Yıldırım, S., \& Saka, O. (2006). Technology adoption of medical faculty in teaching: Differentiating factors in adopter categories. Educational Technology \& Society, 9, 213-22.

Zhang, X., Yu, P., Yan, J., Ton, I., \& Spil, A.M. (2015). Using diffusion of innovation theory to understand the factors impacting patient acceptance and use of consumer e-health innovations: A case study in a primary care clinic. BMC Health Services Research, 15. 